Winter 2004

\title{
Courts and Globalization
}

Sir David Williams David Q. C.

University of Cambridge

Follow this and additional works at: https://www.repository.law.indiana.edu/ijgls

Part of the Courts Commons, and the International Law Commons

\section{Recommended Citation}

Williams, Sir David David Q. C. (2004) "Courts and Globalization," Indiana Journal of Global Legal Studies: Vol. 11 : Iss. 1 , Article 3.

Available at: https://www.repository.law.indiana.edu/ijgls/vol11/iss1/3

This Symposium is brought to you for free and open access by the Law School Journals at Digital Repository @ Maurer Law. It has been accepted for inclusion in Indiana Journal of Global Legal Studies by an authorized editor of Digital Repository @ Maurer Law. For more information, please contact rvaughan@indiana.edu.

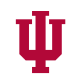

JEROME HALL LAW LIBRARY

INDIANA UNIVERSITY

Maurer School of Law
Bloomington 


\title{
Courts and Globalization
}

\author{
Sir David Williams*
}

There is inevitably a problem of terminology. A professor of government once said that federalism "is what political scientists talk about when they talk about federalism,"1 and one could add that globalization is what political scientists (and lawyers) talk about when they talk about globalization. Moreover, the more one reads about globalization the more uncertain one is about the underlying assumptions behind the use of the term; and it is particularly difficult to assess the changing role and responses of the national courts of law in the face of globalization. One looks in vain for globalization as an item in the index of leading works - certainly in the United Kingdom-on constitutional and administrative law; but there is at the same time a growing recognition of the global implications of many areas of law hitherto regarded as part of national legal systems, as well as an acceptance of the enhanced role of international bodies and tribunals.

Before one is submerged, however, in the welter of considerations touching on international trade, criminal law, privatization, deregulation, international arbitration, the settlement of disputes, the impact of public international law, the protection of the environment, the Internet and the revolution in technology, international cooperation, regional cooperation, terrorism, antitrust laws, and so much else, it is perhaps desirable to look at some recent cases-in the United States, in South Africa, in the United Kingdom, and in Canada-where values or techniques have been adopted and used in national courts in a way not anticipated only a short time ago. This is not to trespass into a discussion at this stage of adjudication by external institutions. The immediate concern is with the possible internationalization of national laws.

In May 2002, Justice Sandra Day O'Connor addressed the Annual Meeting of the American Law Institute on "the internationalization of American law,"

* Professor Sir David Williams QC DL was Vice-Chancellor of the University of Cambridge, 1989-96; President of Wolfson College, 1980-92; and Rouse Ball Professor of English Law, 198392. He is now Vice-Chancellor Emeritus, University of Cambridge. Professor Sir David Williams delivered this article as the keynote address at the Indiana Journal of Global Legal Studies' Symposium "Globalization, Courts, and Judicial Power," held April 11, 2003, at the Indiana University School of Law.

1. William S. Livingston, Introduction to Federation and the Commonwealth: A BiblioGRAPHICAL COMMENTARY xi, xvi-xvii (William S. Livingston ed., 1963). 
and her talk-in the words of Michael Traynor, the President of the ALI"presaged the decision of the Supreme Court a month later in Atkins v. Virginia." In Atkins, ${ }^{3}$ the Supreme Court of the United States held 6-3 that the execution of mentally retarded criminals constituted cruel and unusual punishment under the Eighth Amendment of the Constitution. In the opinion delivered by Justice Stevens on behalf of the majority, it was declared that a national consensus had developed against such executions. Particular attention was paid to the fact that this view was supported by religious and professional organizations within the United States and also by the world community where the imposition of the death penalty for crimes committed by mentally retarded offenders is "overwhelmingly disapproved." One of those dissenting, Chief Justice Rehnquist, failed "to see, however, how the views of other countries regarding the punishment of their citizens provide any support for the Court's ultimate determination." Justice Scalia, also dissenting, spoke of the Court's "embarrassingly feeble evidence of "consensus" and of the irrelevance of the practices of the "'world community' whose notions of justice are (thankfully) not always those of our people;" and, more generally, he rejected the Court's "incremental abolition" of the death penalty. ${ }^{6}$ A not-dissimilar division of views about recourse to trends or decisions in other countries appears in Lawrence $v$. Texas. ${ }^{7}$

In spite of the severity of the dissent by Justice Scalia in the Atkins case, the issues raised in many contexts are bound to reflect globalization or internationalism-not in the sense of comparative law or even of regional law such as that

2. Michael Traynor, The President's Letter, A.L.I. Rep. (Am. Law Inst., Philadelphia, Pa.) Fall 2002, at 1-4; Justice O'Connor's address is published in the Proceedings of The American Law Institute's 79th Annual Meeting (May 15, 2002) at pages 245-51.

3. 536 U.S. 304, $32 \mathrm{l}$ (2002).

4. Id. at $316 \mathrm{n} .21$ (referring explicitly to the view of the European Union).

5. Id. at 325 (Rehnquist, C.J., dissenting). Chief Justice Rehnquist conceded that, in other contexts, the Supreme Court had looked to "the climate of international opinion." Id. (quoting Coker v. Georgia, 433 U.S. 584, 596 n. 10 (1977)).

6. Id. at $344,348,353$ (Scalia, J., dissenting). Justice Scalia cited his own comment, when dissenting in Thompson $v$. Oklahoma, that "where there is not first a settled consensus among our own people, the views of other nations, however enlightened the Justices of this Court may think them to be, cannot be imposed upon Americans through the Constitution." 487 U.S. 815, 868-69 n.4 (2002) (Scalia, J., dissenting).

7. Compare Lawrence v. Texas, 123 S.Ct. 2472, 2481-83 (2003) (Kennedy, J.), with id. at 249495 (Scalia, J., dissenting). See also Virginia v. Black, 123 S.Ct. 1536, 1544 (2003) (referencing the Scottish origins of cross-burning). 
developed by the European Court of Justice, but rather in the sense of cultural standards or values emerging in several countries and influencing each other. The Supreme Court of the United States is receptive to arguments of culture. In Dickerson v. United States, for instance, Chief Justice Rehnquist, delivering the opinion of the court, said that "Miranda has become embedded in routine police practice to the point where the warnings have become part of our national culture," ${ }^{8}$ and he added for good measure that Justice Scalia had in an earlier, unrelated dissent indicated that the fact that a rule has found "'wide acceptance in the legal culture' is 'adequate reason not to overrule it." Once there is reference to "culture" or "legal culture," it is surely difficult to avoid injections from other countries or jurisdictions in circumstances where the evidence is timely and appropriate. The words of Chief Justice Warren in Brown $v$. Board of Education of Topeka ${ }^{10}$ on May 17, 1954, appear on the surface to concern only the United States and its constitutional stance, but issues of racial segregation were already recognized on a worldwide basis. His opinion, "for all its economy" as Richard Kluger put it, was delivered at a moment "when the country had just begun to sense the magnitude of its global ideological contest with Communist authoritarianism and was quick to measure its own worth in terms of megaton power" but demonstrated that the country still stood for "something more than material abundance." In other words, racial segregation was facing rejection in all countries, though no one underestimated the difficulty of securing desegregation in practice.

The process of implementing decisions can also have a global dimension. Consider the decision of the Constitutional Court of South Africa, handed down in July 2002, in Minister of Health v. Treatment Action Campaign, ${ }^{12}$ which concerned the HIV/AIDS pandemic. The applicants in the case, led by the Treatment Action Campaign, sought in a specific area to challenge the government's refusal to make a particular drug available and its failure to set a timetable for a

8. 530 U.S. 428, 443 (2000) (declining to overrule Miranda v. Arizona, 348 U.S. 436 (1966), on the admissibility of statements made during custodial interrogation).

9. 530 U.S. at 443 (quoting Mitchell v. United States, 526 U.S. 314, 331-32 (1999) (Scalia, J., dissenting).

10. 347 U.S. 483 (1954).

11. 2 Richard Kluger, Simple Justice: The History of Brown v. Board of Education and Black America's Struggle for Equality 896 (1976).

12. 2002 (5) SA 721 (CC). 
national programme to prevent mother-to-child transmission of HIV. Provisions in the Bill of Rights, relating to health care services and the special protection afforded to children, were invoked, and the affidavits in support showed "a variety of specialised perspectives, ranging from paediatrics, pharmacology and epidemiology to public health administration, economics and statistics." ${ }^{13}$ Counsel for the government argued that even if the Constitutional Court should find that the government policies fell short of what the Constitution requires, the only competent order available was a declaration of rights, leaving the government to adapt its policies accordingly. The Constitutional Court, however, declined to be tied by a requirement that only declaratory orders could be granted: where a breach of any right has taken place "a court is under a duty to ensure that effective relief is granted.... Where necessary this may include both the issuing of a mandamus and the exercise of supervisory jurisdiction."14

In making that assertion the Constitutional Court looked at foreign jurisdictions, and it found no grounds for suggesting that injunctive relief against the government breaches the separation of powers. This was so even in relatively cautious countries such as Canada and the United Kingdom. Particular encouragement was drawn from the willingness of Indian courts to grant far-reaching remedial orders in such areas as child labor and especially from cases in the United States led by the second desegregation case, Brown v. Board of Education of Topeka in 1955, with its emphasis on implementation and "all deliberate speed." 15 By virtue of the second Brown case the lower courts "would have the power to determine how much time was necessary for the school boards to achieve full compliance with the Court's decision and would also be able to consider the adequacy of any plan proposed by the school boards 'to effectuate a transition to a racially non-discriminatory school system." 16 The Constitutional Court in South Africa was hence more confident in spelling out the steps necessary to comply with the Constitution; it recognized that government faced enormous problems in combating HIV/AIDS and that government policy was evolving; and remedial orders as well as declarations were granted. One suspects

13. Id. at 729 .

14. Id. at 758 .

15. Brown v. Bd. of Educ. of Topeka, 349 U.S. 294, 301 (1955). See Bernard Schwartz, SWanN's Way: The School Busing Case and the Supreme Court 47-66 (1986) (discussing the ramifications of the desegregation decisions of the Warren Court).

16. 2002 (5) SA (CC) at 748 n.57 (referring to Swann v. Charlotte-Mecklenburg Bd. of Educ., 402 U.S. 1 (1971) (setting out some general guidelines to achieve desegregation)). 
that courts in many countries would often be influenced, in the remedy as well as the substance, by parallel developments elsewhere.

There are undoubtedly difficulties in attempting to assess the role of a national judiciary in facing wider aspects of foreign affairs. Some of these were explored by Mr. Justice Lawrence Collins in the F.A. Mann Lecture delivered at Lincoln's Inn in November $2001 .{ }^{17} \mathrm{He}$ explored issues of the prerogative, justiciability, international law (especially treaty law), and judicial restraint, and in his conclusions he accepted the tentativeness of the legal rulings in many instances. Since that lecture, developments in response to the terrorist attacks of September 11,2001, have brought out vividly the global implications of national responses. There have been important cases in the United Kingdom on deportation, extradition, detention without trial in Guantanamo Bay, and even the interpretation of United Nations Resolution $1441 .^{18}$ The claimants in the latter category sought declaratory relief as to the true meaning of Resolution 1441, inviting the court to declare that the British government would be in breach of international law were it to take military action against Iraq without a further resolution. The invitation was declined. The Divisional Court of the Queen's Bench Division denied that it had jurisdiction to declare the true interpretation of an international instrument which had not been incorporated into domestic law and where a person's rights or duties under domestic law were not in issue. Lord Justice Simon Brown, one of the three judges involved, added that the court would in any event refuse to embark upon the determination of an issue "if to do so would be damaging to the public interest in the field of international relations, national security or defence." Moreover, he went on, advisory declarations should not be made "save for demonstrably good reason" and here there was none. ${ }^{19}$ Although counsel were permitted to advance detailed arguments, the application was essentially dismissed on grounds of non-justiciability; and there is no doubt that the holding underlines the tentative and cautious

17. See Lawrence Collins, Foreign Relations and the Judiciary, 51 InT'L \& Comp. L.Q. 485 (2002).

18. See Sec'y of State for the Home Dep't v. Rehman, 1 All E.R. 122, 124 (H.L. 2002); Re Al-Fawwaz, 1 All E.R. 545, (H.L. 2001); Abbasi v. Sec'y of State for Foreign \& Commonwealth Affairs, No. C/2002/0617A0617B, (2002) E.W.C.A. Civ. 1598, 2002 WL 31452052 para. 1 (C.A. 2002); Campaign for Nuclear Disarmament v. Prime Minister, CO/5429/2002, 2002 WL 31676361 para. 1 (Q.B. Div'l Ct. 2002).

19. Campaign for Nuclear Disarmament, 2002 WL 31676361 at para. 47. 
approach to the application of international law by national courts. ${ }^{20}$ Problems as to the application of international law arose also in a slightly earlier case in 2002 when the Court of Appeal addressed the issue of British nationals detained in Guantanamo Bay naval base. Again, after hearing extensive arguments, the Court of Appeal felt obliged to reject the applicants' claim, which had raised important issues about the extent to which the English courts could examine whether a foreign state is in breach of treaty obligations or public international law when fundamental human rights are engaged, the extent to which a decision of the executive in the field of foreign relations is justiciable in an English court, and whether there are any circumstances "in which the court can properly seek to influence the conduct of the executive in a situation where this may impact on foreign relations." ${ }^{11}$

The remarkable feature of these two decisions in the United Kingdom, on Resolution 1441 and on Guantanamo Bay, is that the courts allowed such detailed argument and addressed several important issues. In the Guantanamo Bay litigation, Mr. Justice Richards had on March 15, 2002, refused the application for permission to seek judicial review, but on July 1 the Court of Appeal granted permission and directed a substantive hearing on the important issues raised. ${ }^{22}$ One suspects that the argument of non-justiciability would have prevailed without more ado only a few years ago, but the Court of Appeal emphasized "that the issue of justiciability depends, not on general principle, but on subject matter and suitability in the particular case." ${ }^{23}$ The application failed in the end, as we have seen, but even so the Court of Appeal took note, for instance, of the evidence that the position of the British detainees was being considered at

20. See Collins, supra note 17 , at $509-10$.

21. See Abassi, 2002 WL 31452052, at para. 2.

22. Such issues were raised and discussed by the Foreign Affairs Committee of the House of Commons in a Report published in December 2002. See Foreign Affairs Committee, Second Report, 2002-03, Foreign Policy Aspects of the War against Terrorism, Cm. 196, para. 60-62, available at http://www.parliament.the-stationery-office.co.uk/ $\mathrm{pa} / \mathrm{cm} 200203 / \mathrm{cmselect} / \mathrm{cmfaff} / 196 / 19602 . h$ tm (last visited November 29, 2003). See also Foreign Affairs Committee, Appendices to the Minutes of Evidence, 2002-03, Memorandum from the Center for Constitutional Rights: The Detention of British Nationals in Guantanomo Bay, Cuba, Cm. 196, app. 12, para. 99-106, available at http:// www.parliament.the-stationery-office.co.uk.pa/cm200203/cmselect $/ \mathrm{cmfaff} / 196 /$ 196ap14.htm (last visited November 29, 2003).

23. See Abbasi, 2002 WL 31452052, at para. 85. 
the diplomatic level, that the position of detainees generally in Guantanamo Bay had yet to be ruled on by appellate courts in the United States, and that the InterAmerican Commission on Human Rights had taken up the case of the detainees. The judgement of the Court of Appeal appears to strengthen the trend identified by Mr. Justice Lawrence Collins towards the application-in one form or another —of international law in national courts. ${ }^{24}$

That trend towards the application of international law was also recognized in the Resolution 1441 case, and the Guantanamo Bay decision was referred to by counsel and the Court of Appeal. The decision of the Divisional Court has been described as "plainly correct" as a matter of constitutional law, while at the same time raising the desirability or otherwise of allowing judges "a voice on the content of international law. ${ }^{25}$ In addition, it could be argued that in both cases the courts, evidently ill at ease, were searching for a new formula and the length of the judgements, when both applications could have been stopped at the outset on familiar grounds of justiciability, paradoxically gave prominence to the arguments advanced and, in so doing, served a valuable democratic purpose in the identification of issues of immediate concern. Indeed, in the search for an appropriate judicial role in the face of unprecedented questions of global concern it is important to recognize that a court offers a forum which is open and specific.

Openness is especially significant. A leading writer on open justice has spoken of "the overriding importance that has traditionally been attached to the open conduct of judicial proceedings, by comparison with the indifference with which the practice of secrecy has been allowed to permeate the executive branch of government." ${ }^{26}$ There are inevitably exceptions in such areas as national security, commercial litigation, commercial arbitration and sometimes even criminal law; but in many instances of contemporary concern the courts offer transparency, which in itself contrasts with executive practice in so many areas of political delicacy and controversy, not least where international law obtrudes in the national courts.

24. See, e.g., Kuwait Airways Corp. v. Iraqi Airways, 2 W.L.R. 1353, para. 51 (H.L. 2002) (referencing the speech of Lord Nicholls).

25. See David Pannick QC, "Why the Judges Should Have Their Say On Iraq," The Times (London), March 11, 2003, Law section at 4.

26. Joseph Jaconelli, Open Justice: A Critique of the Public Trial 1 (2002). 
The specific nature of seeking judicial rulings is also important. Irrespective of the final outcome of a particular case, it is helpful to itemize the issues at stake. In the Supreme Court of Canada in 1998 the position of Quebec and possible secession from Canada was raised, and the ruling was that Quebec did not, under the Constitution of Canada or under international law, have the right to secede unilaterally. ${ }^{27}$ The Supreme Court was obliged to consider "momentous questions that go to the heart of our system of constitutional government." ${ }^{28} \mathrm{On}$ the issue of advisory opinions, account was taken of the judicial systems in several European countries which have courts dedicated to the review of constitutional claims; the Supreme Court rejected the view that it could not look at international law; problems of justiciability were unsurprisingly raised; Canadian federalism was seen as "the political mechanism by which diversity could be reconciled with unity;" constitutional law and political culture" with the democratic tradition traced back to Magna Carta and the English Bill of Rights $1689 ;{ }^{30}$ the rule of law was confirmed as "a fundamental postulate of our constitutional structure;" ${ }^{31}$ and on the central issue of secession the Supreme Court looked ahead to a referendum and to negotiation, but emphasized that "it would be naïve to expect that the substantive goal of secession could readily be distinguished from the practical details of secession. The devil would be in the details." ${ }^{32}$ On the last matter, it was stressed that after 131 years of Confederation, "there exists, inevitably, a high level of integration in economic, political and social institutions across Canada." ${ }^{33}$ The Supreme Court went on to deny that international law specifically grants component parts of sovereign states the legal right to secede unilaterally and a number of allied matters, such as the so-called right to self-determination, were considered. In effect the issue of secession was assessed within its national and global implications and the Supreme Court of nine justices was able to identify the relevant legal and constitutional issues with considerable authority.

27. See Re Reference by the Governor in Council concerning certain questions relating to the secession of Quebec from Canada, [1998] 161 D.L.R. (4th) 385.

28. Id. at 393.

29. Id. at 407.

30. Id. at 414-15.

31. Id. at 417 (quoting Roncarelli v. Duplessis, [1959] 16 D.L.R. (2d) 689).

32. Id. at 425-26.

33. Id. at 427. See also William A Schabas, Twenty-Five Years of Public International Law at the Supreme Court of Canada, 79 CAN. B. Rev. 174, 193 (2000). 
Judges in national courts are doubtless aware of global influences both historically as well as at the present day. Professor van Caenegem, in a recent perceptive study of European Law in the Past and the Future, pointed out that European courts of justice, the European Commission, the European Parliament and European laws "have not yet altered the basic fact that people live under national laws which were produced by the sovereign national states. ${ }^{34} \mathrm{He}$ then nevertheless reminded us that medieval and early modern Europe managed without national legal systems:

People lived either under local customs or under the two cosmopolitan, supranational systems-the law of the Church and the neo-Roman law of the universities ... Cross-fertilization was the order of the day, because the law was seen as a vast treasure house from which kings and nations could pick and choose what suited them..$^{35}$

Van Caenegem expressly addressed the English common law, which from the thirteenth century onwards was a truly national system "that was eventually exported by English people who settled in remote continents," but he also stressed the wider international currents reflected in common law applied by English ecclesiastical courts, in the work of the Court of Chancery with its own equity and rules of procedure "which were closer to the Roman-canonical than the common-law model," in the work of the Court of Admiralty which applied the European jus commune "as was natural because of its concern with international shipping on the high seas," in the teaching of Roman and canon law at Oxford and Cambridge, and in the impact of continental jurisprudence in the writings of great jurists such as Bracton and Blackstone. ${ }^{36}$ The European influence in Scottish law was all the greater historically; but, since the United Kingdom's accession to the European Union from 1973 and since the incorporation into domestic law of the European Law of Human Rights by virtue of legislation of 1998, the Europeanization of the common law and of national legislation has

34. R. C. van Caenegem, European Law in the Past and the Future: Unity and Diversity over Two Millennia 1-2 (2002).

35. Id.

36. Id. at 19-21. See also R. C. van Caenegem, An Historical Introduction to Western Constitutional Law (1995). 
continued apace. Globalization is more and more evident through the effect of international agreements and treaties, of joint efforts to combat problems ranging from environmental and security demands to money laundering and international commercial fraud, and not least of the willingness of judges-as we have seen in the cases decided in the United States, South Africa, the United Kingdom and Canada - to accept both the increasing influence of international law and the emergence of ideas and trends in other jurisdictions which can comfortably be adopted or adapted in the process of litigation.

From a constitutional perspective it is noteworthy that the coming together of nations in regional groupings of varying closeness operates alongside the fragmentation of nations or regional groupings in different circumstances. A federal relationship, as normally understood, allows for the cross-fertilization of ideas among like-minded nations or jurisdictions. The United States, Canada (save for the special question of Quebec), and Australia are obvious examples. More ambitious schemes such as that envisaging imperial federation-which originated in the nineteenth century-eventually petered out, but the current arguments about European federation illustrate the passions which can be aroused. Federations in the past have broken apart when the conditions for acceptable federal union were not present: an attempted federation in the West Indies collapsed in 1962 after only four years, and a Central African Federation-of Southern Rhodesia, Northern Rhodesia and Nyasaland-succumbed in late 1963 after only ten years. ${ }^{37}$ Other regional groupings, whether federal or not, have also fallen apart: consider the former Yugoslavia or, dramatically, the former Union of Soviet Socialist Republics (U.S.S.R.). Both World Wars in the last century produced extensive changes in national boundaries as well as in groupings such as the Austro-Hungarian Empire, reminding us that globalization does not necessarily mean stability or permanence.

Since the early twentieth century there has been growing pressure for a world order which transcends national boundaries, whatever the internal constitutional system. At the conclusion of the First World War, President Woodrow Wilson had a vision of "a League of Nations to provide the collective security that, in a well-run civil society, was provided by the government, its laws, its courts and its police." 38 The covenant of the League of Nations was duly

37. See John Kendle, Federal Britain: A History 137 (1997).

38. Margaret MacMillan, Peacemakers: The Paris Conference of 19 I 9 and Its Attempt to END WAR 21 (paperback ed. 2002). 
adopted, but-as one historian has put it-its "very name evokes images of earnest bureaucrats, fuzzy liberal supporters, futile resolutions, unproductive factfinding missions and, above all, failure ...."39 Yet the League of Nations demonstrated a "confederate" if not federal desire, and Wendell Willkie, the defeated presidential candidate of 1940, confessed in 1943 that he had been a believer in the League and he believed that its rejection in the United States was disastrous. ${ }^{40} \mathrm{His}$ words appeared in a book called One World, which predated the establishment of the United Nations with "its more institutional structure and normative and executive power than was possessed by the League of Nations...." ${ }^{\prime 41}$ The United Nations in its turn provided the focus as post-war developments, especially in the economic area, took one nation after another into acceptance of international or multi-national agreements together with new efforts at cooperation and dispute resolution. ${ }^{42}$ The globalization of world trade has generated a large corpus of legal and other writing, and specific, traditional areas of domestic law-including administrative law and antitrust law-are directly affected. ${ }^{43}$ International organizations such as the World Trade Organization became increasingly prominent and major commercial developments are increasingly global as well as national in their implications. The events in Seattle in 1999 revealed the scale of opposition as well as support for bodies such as the World Trade Organization. ${ }^{44}$

Globalization, however, is not simply an economic issue. The adoption in 1948 of the Universal Declaration of Human Rights, which has been described as "the parent document of the modern human rights movement," 45 encouraged the drafting of the European Convention on Human Rights which came into

39. Id. at 92 .

40. See Wendell L. Willkie, One World 62-63 (1943).

41. G. F. Sawer, Modern Federalism 61 (1969).

42. See, e.g., J. G. Merrills, International Dispute Settlement 197-98 (1998); Thomas C. Fischer, The United States, the European Union, and the "Globalization" of World Trade 38-43 (2000); Peter Singer, One World: The Ethics of Globalization 51-105 (2002).

43. See e.g., Alfred C. Aman Jr., Administrative Law in a Global Era (1992); Global Administrative Law Symposium, 54 Admin. L. Rev. 409, 409-511 (2002); Lucio Lanucara, The Globalization of Antitrust Enforcement: Governance Issues and Legal Responses, 9 IND. J. Global Legal Stud. 433 (2002).

44. Singer, supra note 42, at 51-105.

45. Mary Ann Glendon, A World Made New: Eleanor Roosevelt and the Universal Declaration of Human Rights xxi (2001). 
force in 1951 and was incorporated into our domestic law in the United Kingdom by virtue of legislation of 1998 . The changed attitude to the formulation of human rights represents a remarkable change in the legal culture of the United Kingdom, sometimes in unexpected ways. In a recent prisoners' rights case, for instance, Lord Woolf (the Lord Chief Justice) complained about the large number of authorities cited. "In these human rights cases," he said, "the volume of cases reported is being increased daily and parties must exercise restraint as to their citation. It is the principles which are relevant and important." ${ }^{36}$ The volume of cases cited, however, is a symptom of global issues of human rights and the readiness of lawyers and judges to seek guidance from the experience of other jurisdictions, in Europe and beyond.

Following on the International Military Tribunal which sat at Nuremberg at the end of the Second World War, there has been some movement towards the assertion of national jurisdiction over those alleged to have committed crimes against humanity, even where the country or countries involved were not party to an international agreement such as the Convention Against Torture, 1989. Many lawyers prefer the setting up of international tribunals: Slobodan Milosevic faces such a special body set up in 1993 with regard to the former $\mathrm{Yu}$ goslavia. Following on an initial international agreement of 1998, the International Criminal Court (I.C.C.) has been established and it was formally opened in the Hague on March 11, 2003. The I.C.C. has jurisdiction over genocide, crimes against humanity, and war crimes. We are only at the beginning of its work and there will be many difficulties to face, not least because of the hostility shown by the United States; but the British judge on the I.C.C., Sir Adrian Fulford, has described it as "an incredibly important development for international justice and world peace." 47

These references to the wide sweep of international concern with and adjudication upon so many political, economic, criminal and other matters touch

46. Regina v. Sec'y of State for the Home Dep't, 1 W.L.R. 545, 565 (C.A. 2002).

47. Stephan Castle, Half a Century After Nuremberg, World Criminal Court Opens, The Independent (London), March 11, 2003, at 15. See also William A. Schabas, An Introduction to the International Criminal Court (2001); Singer, supra note 42, at 118; Kerem Altiparmak, The International Criminal Court Act 2001, New L.J. 942, 942 (2001); Robinson Deplores U.S. Absence from International Criminal Court; Wood, Trooboff, Abrahamson, and Carlton Also Speak at Annual Meeting, A.L.I. ReP. (Am. L. Inst., Philadelphia, Pa.), Summer 2003, at 3, 7 . 
upon the huge and often uncharted spread of globalization. This Symposium will continue the process of exploration. At the same time we would do well to recognize the ebb and flow of multinational developments over the centuries and also to appreciate, as the cases discussed at the outset tend to show, that cultural changes emerge unexpectedly in ordinary national courts. 


\section{Now available online to institutions}

\section{PROBLEMS OF POST-COMMUNISM}

Editor: Robert T. Huber, National Council for Eurasian and East European Research (NCEEER)

Associate Editors:

Andrew Michta, Rhodes College

Bruce Dickson, George Washington University

Managing Editor: Ann E. Robertson, NCEEER

The most rapidly changing societies of Europe and Asia are the countries emerging from communist rule. For insight into the ongoing revolution in the post-Wall world, there is no better source than Problems of Post-Communism. $P P C$ features readable analysis, reliable information, and lively debate about the communist and post-communist world. Emphasis is placed on timely research covering current economic, political, security, and international developments and trends in Russia and China, Central Europe and Central Asia, and East and Southeast Asia.

"One of the most relevant and readable foreign affairs journals for both policymakers and scholars following the ongoing transitions in Central and Eastern Europe and Eurasia."

- Ken Roberts, Bureau of Intelligence and Research, U.S. State Department

ISSN 1075-8216 / Published since 1951 / Frequency: 6 2004 Volume: Vol. 51 (Jar/Feb 2004 - Nov/Dec 2004)

US Institutional Subscription Rate: $\$ 225.00$

US Individual Subscription Rate: $\$ 49.00$

Foreign Institutional Subscription Rate: $\$ 285.00$

Foreign Individual Subscription Rate: $\$ 70.00$

\section{RUSSIAN POLITICS \& LAW}

\section{A Journal of Translations}

\section{Editor: Nils H. Wessell, U.S. Coast Guard Academy}

Russian Politics \& Law surveys the most important and provocative work in the post-Soviet political arena. Articles cover domestic and foreign policy, legislative development, law enforcement, intra- and intergovernmental relations, and political party development.

ISSN 1061-1940 / Published since 1962 / Frequency: 6 2004 Volume: Vol. 42 (Jan/Feb - Nov/Dec 2004) US Institutional Subscription Rate: $\$ 1,150.00$ US Individual Subscription Rate: $\$ 135.00$

Foreign Institutional Subscription Rate: $\$ 1,270.00$

Foreign Individual Subscription Rate: $\$ 207.00$
STATUTES AND DECISIONS

The Laws of the USSR and Its Successor States

\section{A Journal of Translations}

\section{Editor: Sarah J. Reynolds}

The definitive source for analysis and reliable translation of the building blocks of a new legal regime. Among the topics covered in the journal's thematic series are developments in economic law (de-monopolization, market regulation, consumer protection); the Russian Constitutional Court; Russian electoral law; criminal law; and the evolving federalist system.

ISSN 1061-0014 / Published since 1964 / Frequency: 6 2004 Volume: Vol. 40 (Jan/Feb - Nov/Dec 2004) US Institutional Subscription Rate: $\$ 1,275.00$ US Individual Subscription Rate: $\$ 170.00$ Foreign Institutional Subscription Rate: $\$ 1,395.00$ Foreign Individual Subscription Rate: $\$ 211.00$

\section{CHINESE LAW \& GOVERNMENT}

\section{A Journal of Translations}

Editor: James Tong, University of California, Los Angeles

Chinese Law $\mathcal{E}$ Government surveys the most important and provocative Chinese works in the fields of law, politics, and government. It features unabridged translations of important policy documents and scholarly works, and also includes works of major significance from Japanese, Russian, and Taiwan sources.

ISSN 0009-4609 / Published since 1968 / Frequency: 6 2004 Volume: Vol. 37 (Jan/Feb - Nov/Dec 2004) US Institutional Subscription Rate: $\$ 1,150.00$ US Individual Subscription Rate: $\$ 140.00$ Foreign Institutional Subscription Rate: $\$ 1,270.00$ Foreign Individual Subscription Rate: $\$ 212.00$

\section{M.E. Sharpe}

TO ORDER: CALL 800-541-6563 or 914-273-1800 FAX 914-273-2106 www.mesharpe.com 